\title{
UMA ABORDAGEM HISTÓRICA SOBRE O ENSINO DA ADMINISTRAÇÃO NO BRASIL
}

\author{
A HISTORICAL APPROACH TO MANAGEMENT EDUCATION IN BRAZIL
}

DOI: http://dx.doi.org/10.12712/rpca.v6i4.250

\section{Vera Regina Ramos Pinto \\ verreg28@gmail.com}

Escola Brasileira de Administração Pública e de Empresas (EBAPE) - Fundação Getúlio Vargas (FGV) Rio de Janeiro - RJ, Brasil

\section{Mario Divo Motter Junior}

mdivo@attglobal.net

Escola Brasileira de Administração Pública e de Empresas (EBAPE) - Fundação Getúlio Vargas (FGV) Rio de Janeiro - RJ, Brasil

\section{Resumo}

O objetivo deste estudo é o de apresentar uma abordagem histórica relacionada ao ensino da Administração no Brasil, ao longo do tempo. Buscou-se identificar um referencial bibliográfico que pontuasse o surgimento das escolas de Administração, com os respectivos cenários políticos e/ou econômicos, até a descrição do contexto atual dos cursos superiores oferecidos no país. O crescimento das matrículas no sistema de ensino superior, nas duas últimas décadas, com foco em cursos de Administração, são evidenciados nesse artigo.

Palavras-chave: Administração. História da Administração. Pesquisa em administração. Ensino superior.

\begin{abstract}
The purpose of this study is to develop a historical approach on the management education in Brazil, throughout the time. We sought to raise a bibliographic reference on the Brazilian business schools, including the political and / or economic scenarios. The authors also present updated information about the education offered in Brazil. The article highlights the growth of enrollments in higher education system, over the last two decades, especially in management courses.
\end{abstract}

Keywords: Management. Management history. Management research. Higher education. 


\section{Introdução}

Esse artigo apresenta uma visão histórica sobre a evolução da educação superior de Administração no Brasil, ao longo do tempo. Apesar do exame da literatura disponível ter sido aprofundado, os autores acreditam que muita contribuição nova possa trazer um complemento desejável ao assunto. 0 primeiro momento em que se pode falar de educação superior, no Brasil, deu-se em 1808, quando a Corte Portuguesa se transferiu para o Rio de Janeiro, trazendo recursos e o interesse em investimentos com claro objetivo de criar e garantir condições para uma boa qualidade de vida. Nessa ocasião, foram instituídos os primeiros cursos em nível superior no Brasil.

Com a Proclamação da República, em 1889, o Brasil se constituiu como um Estado federativo, facilitando que iniciativas estaduais pudessem ser levadas avante, incluindo aquelas relacionadas ao ensino superior. Surgem, então, a Universidade de Manaus (1909), a de São Paulo (1911) e a do Paraná (1912), como exemplos. Seguindo a linha do tempo, o país entra no cenário econômico de expansão comercial, provocando a necessidade de se organizar o ensino comercial, inclusive o de nível superior.

A diversificação da agricultura, um maior desenvolvimento das atividades industriais, a expansão de empresas já existentes e o surgimento de novos estabelecimentos ligados a indústria de base foram importantes sinais do processo de complexificação pelo qual passava a economia brasileira. Junto com estas mudanças observadas no quadro econômico, processava-se a ampliação dos setores urbanos com o crescimento das camadas médias, da classe trabalhadora e a diversificação de interesses no interior das próprias elites econômicas. Em seu conjunto estas transformações funcionariam como elementos de estímulo a alterações no quadro político vigente colocando em questionamento as bases do sistema oligárquico da Primeira República (FERREIRA e PINTO, 2006).

A Era Vargas imprimiu uma série de mudanças estruturais com ênfase, principalmente, nas bases do desenvolvimento do Brasil e na industrialização orientada pelo Estado. Por isso, essa fase foi de fundamental importância para o desenvolvimento da Administração no Brasil, tanto na área pública quanto na área privada, uma vez que o país demandava por profissionais qualificados para atuarem na complexidade crescente dos órgãos estatais e no crescimento das empresas privadas.

Como consequência, o governo Vargas criou a Fundação Getúlio Vargas (FGV), em 1944, com o objetivo de desenvolver pesquisa e ensino na área da Administração. Em 1952, a FGV cria a Escola Brasileira de Administração Pública - EBAP, no Rio de Janeiro, como a primeira escola de Administração Pública do Brasil e da América Latina e, em 1954, institui a Escola de Administração de Empresas de São Paulo - EAESP, contribuindo sobremaneira com a formação de novos administradores, sendo hoje referência na área de Administração.

A profissão de Administrador foi regulamentada em 1965 e o currículo dos cursos de Administração sofreu, basicamente, três ciclos de mudanças que buscaram a adequação às exigências do mercado, o qual trazia novas demandas a partir da implantação de tecnologias administrativas mais atualizadas.

Com a promulgação da Constituição Brasileira de 1988, a qual estabelece vários quesitos relacionados com o ensino superior, tornou-se necessário flexibilizar e ampliar o sistema, melhorar os processos de avaliação com foco na qualidade da educação e atender à demanda 
crescente do mercado por profissionais qualificados.

Nos últimos anos do século XX, impulsionado pelo modelo político e econômico vigente, o sistema de educação superior experimentou crescimento relevante na oferta de vagas, principalmente relacionado às instituições privadas.

Após essa breve introdução, o artigo comenta da metodologia adotada e traz breve histórico sobre a educação superior, incluindo a análise da estruturação do ensino de Administração e uma exposição das Instituições de Ensino Superior (IES) brasileiras, apresentando dados estatísticos afins às IES relacionadas com cursos de Administração.

\section{Metodologia}

Para este artigo, o processo metodológico utilizou-se essencialmente da pesquisa bibliográfica, realizada a partir do conteúdo de livros, dissertações, teses e artigos relacionados ao tema de interesse, quais sejam: história das universidades no Brasil, evolução do ensino superior de Administração e estrutura atual do sistema de ensino superior. As buscas foram realizadas em bibliotecas e em vários sítios na internet.

A principal vantagem da pesquisa bibliográfica reside no fato de permitir ao investigador a cobertura de uma gama de fenômenos muito mais ampla do que aquela que poderia pesquisar diretamente. Essa vantagem torna-se particularmente importante quando o problema de pesquisa requer dados muito dispersos pelo espaço (GIL, 2002, p. 45).

A pesquisa também se utilizou da investigação documental, uma vez que analisou leis, decretos, portarias, resoluções e documentos conservados por órgãos públicos ou privados, com especial atenção sobre a estruturação das universidades e do ensino da Administração, além da legislação pertinente às reformas administrativas.

Gil (2002) considera que existem muitas semelhanças entre a pesquisa bibliográfica e a documental. Pare ele, a principal diferença está na natureza das fontes, uma vez que a investigação bibliográfica se utiliza, essencialmente, de contribuições de vários pesquisadores sobre um tema ou fenômeno, e a pesquisa documental faz uso de fontes que não receberam tratamento analítico ou que podem ser estudadas de acordo com um tema em particular.

Com relação aos fins, de acordo com Vergara (2004), a presente pesquisa pode ser classificada como exploratória, uma vez que durante os levantamentos bibliográficos não foram encontrados registros relacionados a todos os temas de interesse, em quantidade significativa, evidenciando haver pouco conhecimento acumulado e sistematizado sobre esses temas. Além disso, as pesquisas exploratórias também têm por finalidade "aumentar a familiaridade do pesquisador com um ambiente, fato ou fenômeno, para a realização de uma pesquisa futura mais precisa, ou modificar e clarificar conceitos" (MARCONI e LAKATOS, 2010, p. 171).

\section{O nascimento da universidade no Brasil}

A referência histórica das universidades, no Brasil, começa somente a partir de 1900. Até essa data, as elites brasileiras primavam por desenvolver seus estudos superiores nas universidades europeias. Diferentemente dos colonizadores espanhóis, que na época da independência do Brasil já haviam fundado quase 30 universidades em suas colônias na América, os portugueses resistiam em criar uma universidade na colônia. Eles consideravam que os filhos das classes mais abastadas deveriam continuar seus estudos na Universidade de 
Coimbra (CUNHA, 1980; MARTINS, 1990; FÁVERO, 2006). Além disso, a burguesia brasileira não considerava necessária a criação de universidades no Brasil, por entenderem que realizar os estudos em instituições europeias de ensino superior seria mais apropriado.

Dessa forma, a Coroa Portuguesa frustrou várias iniciativas de criação de universidades, inclusive dos jesuítas, responsáveis pelos colégios no Brasil, que tentaram criar uma universidade ainda no século XVI (FÁVERO, 2006). No período colonial (MARTINS, 1990), quem tivesse a aspiração em dar prosseguimento aos estudos deveria procurar a instituição portuguesa de ensino superior em Coimbra, caso a intenção fosse estudar Teologia ou Direito. Se, porventura, o interesse fosse estudar medicina, a Universidade procurada deveria ser a de Montpellier, na França.

De acordo com Martins (1990), esse atraso se explica porque era conveniente para a Coroa Portuguesa manter o controle centralizado do ensino superior, representado principalmente pela Universidade de Coimbra, a qual passou a ter papel primordial na formação das elites culturais da colônia brasileira, garantindo formação alinhada às suas ideologias. Portugal foi exitoso em abafar várias tentativas de criação de universidades nos períodos colonial e monárquico, garantindo a continuidade da dependência cultural e política da colônia (MENDONÇA, 2000; FÁVERO, 2006).

Teixeira (1989) chama a atenção para o fato de que, até a Independência do Brasil, um estudante brasileiro na Universidade de Coimbra era considerado um português nascido no Brasil e não um estrangeiro, podendo, inclusive, ser professor da referida instituição. 0 autor ainda afirma que a Universidade de Coimbra foi uma típica universidade brasileira, até o início do século XIX, tendo formado mais de 2500 estudantes nascidos no Brasil.

Com a transferência da Corte portuguesa para o Rio de Janeiro, em 1808, D. João VI criou várias instituições consideradas de ensino superior, pautadas em atender às preocupações relativas à defesa militar da colônia (MENDONÇA, 2000). Destacam-se as criações da Academia de Marinha, em 1808, e a Academia Real Militar, em 1810, com objetivo de formar oficiais e engenheiros civis e militares. A partir de então, outros cursos e/ou cadeiras foram instituídos no Brasil, tendo como principal motivação a criação e a garantia de uma boa infraestrutura para a sobrevivência da corte. Destacam-se, dentre eles, "a cadeira de economia (1808) e os cursos de agricultura (1812), química (1817) e desenho industrial (1817)”, criados na Bahia, e "o laboratório de química (1812) e o curso de agricultura (1814)", criados no Rio de Janeiro (Fávero, 2006, p. 20).

Após a Proclamação da República, em 1889, várias tentativas de criação de universidade foram idealizadas. Fávero (2006) destaca que, na Constituição de 1891, o ensino superior foi mantido como atribuição do Poder Central, porém sem a exigência de exclusividade. Mendonça (2000, p. 136) ressalta que "a adoção do sistema federativo propiciou algumas iniciativas de criação de universidades, por alguns estados”.

Embora o surgimento da universidade, apoiado em ato do Governo Federal, continuasse sendo postergado, o regime de "desoficialização" do ensino acabou por gerar condições para o surgimento de universidades, tendendo o movimento a deslocar-se provisoriamente da órbita do Governo Federal para a dos Estados. Nesse contexto surge, em 1909, a Universidade de Manaus; em 1911 é instituída a de São Paulo e, em 1912, a do Paraná (MICHELOTTO, 2006) como instituições livres (FÁVERO, 2006, p. 21).

A criação da Universidade de Manaus, em 1909, ocorreu como um dos reflexos da 
prosperidade econômica causada pelo ciclo da borracha. Nessa época, além de atrair mão de obra de outras regiões do país para as atividades relacionadas com a extração da borracha, a região amazônica atraía também muitas pessoas que tinham interesse em ganhar dinheiro com o comércio e outras profissões liberais, tendo em vista o grande potencial de desenvolvimento na região (CUNHA, 2007; MARTINS, 1990). 0 objetivo era criar "uma Escola Militar Prática para oferecer um curso preparatório e um curso superior para a formação militar dos oficiais da Guarda Nacional e outras milícias, assim como para a formação de qualquer cidadão brasileiro" (CUNHA, 2007, p. 176).

De acordo com Cunha (2007), em virtude da decadência do ciclo da borracha, a primeira tentativa brasileira na criação de sua própria Universidade chegou ao fim em 1926, resultando na fragmentação de seus cursos. Na época, permaneceu apenas a Faculdade de Direito, que seria incorporada à Universidade do Amazonas, anos mais tarde.

Com o mesmo destino que a Universidade de Manaus, a então Universidade de São Paulo teve breve história, desaparecendo em 1917, e a Universidade do Paraná viu seu final em 1915.

Assim, malgrado houvesse já o Brasil adentrado no século XX há cerca de duas dezenas de anos e na República há mais de três décadas, sobrevivia impertinente a nossa (quiçá atávica) resistência à Universidade (Martins, 1990, p. 10).

Fávero (1999) destaca que foi somente em 1915, a partir da chamada Reforma Carlos Maximiliano, que o Governo Federal passou a tratar da criação da universidade como instituição. 0 art. 6º, do Decreto $\mathrm{n}^{\circ}$ 11.530, determinou que: "O Governo Federal, quando achar oportuno, reunirá em Universidade as Escolas Politécnica e de Medicina do Rio de Janeiro, incorporando a elas uma das Faculdades Livres de Direito dispensando-a da taxa de fiscalização e dando-lhe gratuitamente edifício para funcionar".

Exatamente por conta dessa disposição governamental, muitos autores consideram que a primeira universidade do Brasil foi a Universidade do Rio de Janeiro, instituída em 1920, a partir do Decreto no 14. 343, o qual reuniu as três instituições de ensino: Politécnica, Medicina e Direito. Ou seja, os autores que defendem que a Universidade do Rio de Janeiro foi a primeira universidade do Brasil o fazem por esta ser fruto de uma determinação do governo federal e também por conta da referida universidade existir até hoje (MARTINS, 1990).

Mas há uma história pitoresca acerca da criação da Universidade do Rio de Janeiro, e quem conta qual a inusitada motivação do governo brasileiro em criá-la é Darcy Ribeiro (1986, p. 9)

[A primeira Universidade do Brasil] se cria por decreto, por uma razão muito importante, ainda que extra-educacional: o rei da Bélgica visitava o Brasil, e o Itamarati devia dar a ele o título de Doutor Honoris Causa. Não podendo honrar ao reizinho como o protocolo recomendava, porque não tínhamos uma universidade, criou-se para isto a Universidade do Brasil. Assim, Leopoldo se fez doutor aqui também. Assim foi criada a primeira universidade brasileira. Uma universidade que, desde então, se vem estruturando e desestruturando, como se sabe.

\section{0 ensino de administração}

Os achados relacionados com as primeiras iniciativas no ensino da Administração, no Brasil remetem ao início do século XX, quando o país encontrava-se em plena expansão comercial e quando as exigências de caráter administrativo se faziam presentes, ocasionando a 
necessidade de se organizar o ensino comercial.

Dessa forma, em 1902, são criadas duas instituições particulares de ensino, a saber: a Academia de Comércio do Rio de Janeiro e a Escola Prática de Comércio de São Paulo que, posteriormente, passou a se chamar Escola Álvares Penteado. Embora o ensino não fosse regulamentado nessa época, na publicação do Decreto Federal 1.339, em 1905, o Governo Federal declarou as duas instituições como de utilidade pública, e os diplomas conferidos pelas mesmas passaram a ser reconhecidos em todo o território nacional (NICOLINI, 2004; BIELINSKI, 2012; FECAP, 2012).

A crise de 1929, também conhecida como "A Grande Depressão", enfrentada pelos Estados Unidos da América e que ocasionou a quebra da Bolsa de Valores de Nova York, teve reflexos em muitos países do mundo, inclusive no Brasil. Os EUA eram o principal comprador do café brasileiro e, com a crise, reduziram muito a aquisição desse produto, provocando seu declínio econômico. A decadência da oligarquia latifundiária, principalmente a cafeeira, contribuiu para que houvesse a transferência de investimentos para outros setores da economia, como o sistema comercial, o de serviços e o bancário.

Além disso, começou-se a investir no setor industrial, que dava seus primeiros passos no país, e que se tornaria o principal fator de desenvolvimento, nos anos seguintes. Essas mudanças demandaram a preparação de profissionais em várias áreas de especialização e em novos métodos de trabalho (PELEIAS et. al., 2007; NICOLINI e FISCHER, 2007). "Eram necessidades criadas pelo crescimento econômico, pelo desenvolvimento de infraestrutura social e pela infraestrutura nascente de transportes, energia e comunicações" (NICOLINI, 2004, p. 7).

A partir de 1930, houve o início da chamada Era Vargas, a qual foi fortemente marcada pela construção de um Estado forte e interventor na economia, bem como pela ênfase na industrialização e no desenvolvimento no país. Para muitos autores a Era Vargas (1930 a 1945) foi fundamental para a criação das bases do Estado Administrativo no Brasil (COELHO, 2006; FÁVERO, 1999; NICOLINI, 2004; NICOLINI e FISCHER, 2007; ROMUALDO, 2012).

O deslocamento do centro dinâmico da economia brasileira para um sistema industrial, trazendo à tona o processo de urbanização, impeliu o Estado para investimentos na indústria de base, na infraestrutura de comunicações, transporte e energia e nas políticas sociais. Para se desincumbir desses encargos - residuais ou inexistentes anteriormente -, seguiram-se a criação de ministérios, autarquias e sociedades de economia mista, transformando as feições da administração pública para o fomento do desenvolvimento econômico-social (COELHO, 2006, p. 14).

Na área educacional, ainda em 1930, foi criado o Ministério da Educação e Saúde Pública responsável pela elaboração e implementação de reformas de ensino nos níveis secundário, superior e comercial, com forte apelo centralizador. De acordo com Fávero (1999), a intenção do Ministério era alinhar a educação escolar às diretrizes definidas no campo político e no campo educacional, criando e desenvolvendo um ensino voltado à modernização do país e que contribuísse com a formação de elites e a capacitação para o trabalho.

Na área do ensino superior, a partir do Decreto-lei no 20.158, de 30 de julho de 1931, que tratou da organização do ensino comercial, foi criado, entre outros, o primeiro Curso Superior de Administração e Finanças, com duração de três anos. "Esse curso diplomava os bacharéis em Ciências Econômicas, ainda que com forte preocupação quanto à capacitação 
administrativa dos novos profissionais" (NICOLINI, 2003, p. 7).

O ensino comercial parece ter influenciado fortemente o surgimento dos cursos superiores de Contabilidade, Administração e Economia (PELEIAS et. al., 2007). Sans e Cytrynowicz apud Peleias et. al. (2007, p. 21)

apontaram que, para o ensino comercial identificado com a formação do contador, havia um aprendizado formal de técnicas de gestão dos negócios e que os três cursos eram um desdobramento do ensino comercial. Concluíram sua pesquisa evidenciando que a distinção entre os cursos é recente e muitas funções exercidas por tais profissionais possuem sobreposições até os dias atuais.

Essa visão é corroborada pelas disciplinas do Curso Superior de Administração e Finanças que, de acordo com o art. 7ํㅡㄹ do Decreto-lei nํㅡ 20.158, estavam assim distribuídas:

- Primeiro ano:

a) Contabilidade de transportes, b) Matemática financeira, c) Geografia econômica, d) Direito constitucional e civil, e) Economia Política.

- Segundo ano:

a) Contabilidade pública, b) Finanças e Economia bancária, c) Direito internacional comercial, d) Ciência da administração, e) Legislação consular, f) Psicologia, lógica e ética.

- Terceiro ano:

a) Direito administrativo, b) Política comercial e regime aduaneiro comparado, c) História econômica da América e fontes da riqueza nacional, d) Direito industrial e operário, e) Direito internacional, Diplomacia, História dos Tratados, Correspondência consular e diplomática, f) Sociologia.

Nesse contexto, em 1931, um grupo de empresários e intelectuais paulistas se reúne e cria o Instituto de Organização Racional do Trabalho (IDORT), considerada a primeira instituição de treinamento em administração da América Latina. A intenção era identificar os principais pesquisadores da administração clássica e científica e disseminar suas respectivas teorias, com vistas a aprimorar a capacidade gerencial dos profissionais e trazer soluções para os problemas relacionados com a administração das empresas em geral. Em 1936, o IDORT é considerado como de utilidade pública pelo Estado. (COELHO, 2006; NICOLINI, 2003).

Se, por um lado, o IDORT introduziu no setor industrial os processos de organização científica do trabalho e da produção, por outro lado o governo prestigiou a administração pública criando o DASP - Departamento de Administração do Serviço Público, em 1938. O DASP foi instituído para constituir um modelo de eficiência no serviço público federal e criar canais mais democráticos relacionados com o recrutamento e a seleção de recursos humanos para a administração pública, a partir de concursos públicos.

As atribuições do DASP, descritas no Decreto-lei nº 579/38, de 30 de julho de 1938, foram:

- Realização de estudos detalhados de repartições, departamentos e estabelecimentos públicos para determinar as modificações a serem feitas em vários campos: dotação orçamentária, distribuição, processos de trabalho, relações entre os órgãos e relações com o público.

- Fiscalizar a execução do orçamento, juntamente com o presidente da 
República.

- Organizar anualmente a proposta orçamentária a ser enviada à Câmara dos Deputados; cuidar da organização dos concursos públicos para cargos federais do Poder Executivo; aperfeiçoamento dos servidores civis da União; auxílio ao presidente no exame dos projetos de lei submetidos à sanção e fixação de padrões para os materiais usados nos serviço público.

A partir de então, e de acordo com Nicolini (2003), a Administração passou a ter importância e a conquistar cada vez mais espaço. As instituições públicas e as empresas passaram a demandar administradores que fossem capazes de dar conta de estruturas complexas e burocráticas. Uma das grandes iniciativas na direção de formar administradores, nessa época, vem de um padre jesuíta que resolveu fazer uma viagem aos Estados Unidos da América, mais precisamente, para a Universidade de Harvard, (FEI, 2012; EGOSHI, 2012) em busca de um modelo de curso de graduação em administração, a ser implementado no Brasil.

Formado na Companhia de Jesus, o Padre Roberto Sabóia de Medeiros (1905-1955) era uma figura muito preocupada com questões sociais e, também, com a educação. Além disso, por estar sempre atento às principais necessidades do país, no começo da década de 1940 ele pressentiu os rumos que o Brasil seguiria na rota da industrialização, principalmente após a Segunda Guerra Mundial, e anteviu que a contratação de gestores especializados para administrar racionalmente os negócios seria essencial (FEI, 2012).

A escolha do padre jesuíta não poderia ter sido melhor pois a Universidade de Harvard, fundada em 1908, nos Estados Unidos, é hoje a maior referência mundial em Ciência da Administração. Utilizando o modelo de ensino da Graduate School of Business Administration de Harvard, ele criou a Escola Superior de Administração de Negócios (ESAN), no Bairro da Liberdade, em São Paulo. 0 principal objetivo da ESAN era formar técnicos de nível superior, a quem se poderia confiar a missão de chefiar e dirigir empresas, para atender a uma demanda que repentinamente passou a existir e que cresceria cada vez mais no Brasil (FEI, 2012).

A ESAN, criada em 1941, tornou-se a primeira escola de Administração do Brasil e da América Latina, com uma característica muito interessante pois, desde a sua fundação, firmou parcerias com empresas paulistas, tais como: SIAN Torquato di Tella, Companhia Antarctica Paulista, Calçados Scatamacchia, Isnard, A Exposição-Clipper e Nadir Figueiredo (EGOSHI, 2012). Na realidade, foram os empresários paulistas que orientaram recursos para a criação da ESAN, uma vez que vislumbravam a necessidade de formar profissionais capazes de dirigir empresas da indústria e do comércio (NICOLINI, 2003). 0 curso oferecido, inicialmente, tinha duração de dois anos seguidos de um ano de especialização. Além disso, qualquer aluno que tivesse ou não o certificado de conclusão do curso secundário poderia se inscrever.

De acordo com Egoshi (2012), o reconhecimento da ESAN foi requerido em 1959 e conseguido em 1961, por decreto assinado por Juscelino Kubitschek de Oliveira, que também validou diplomas dos primeiros alunos formados. E durante 5 anos, a ESAN foi uma "estrela solitária", até que, em 1946, foi criada a Faculdade de Economia e Administração da Universidade de São Paulo (FEA-USP). No entanto, Nicolini (2003b) salienta que essa universidade oferecia cursos de Ciências Econômicas e Ciências Contábeis, tendo em seus currículos disciplinas voltadas às questões administrativas e não sendo um curso específico de Administração. A FEA-USP somente criou os cursos de Administração de Empresas e de Administração Pública no ano de 1964.

Na mesma época, assim como o Padre Sabóia de Medeiros olhou pela ótica da iniciativa 
privada, o então presidente do DASP, Luís Simões Lopes, motivado pelo crescimento do Estado e pela busca da eficiência, articulou a criação da Fundação Getúlio Vargas como uma instituição voltada ao estudo e ao ensino da Administração. Nasceu a FGV em 20 de dezembro de 1944, no Rio de Janeiro (na época Distrito Federal), tendo seu patrimônio sido constituído a partir da contribuição de órgãos públicos e de empresas privadas (CPDOC, 2012). No início, a FGV tinha como objetivo qualificar profissionais tanto para a administração pública quanto para a administração privada. Com a sua continuidade, ampliou a atuação nas ciências sociais, direito e economia, bem como avançou na área da pesquisa.

Em 22 de setembro de 1945, promulgado o Decreto-lei no 7.988, modificações sensíveis ocorreram no âmbito de cursos superiores. Além de alterar o nome da Faculdade Nacional de Política e Economia para Faculdade Nacional de Ciências Econômicas, o decreto-lei criou o primeiro curso superior de Ciências Contábeis do Brasil, ao tempo em que extinguiu o Curso Superior de Administração e Finanças.

Art. 7ํ A Faculdade Nacional de Política e Economia, criada, na Universidade do Brasil, pela Lei no 452, de 5 de julho de 1937, passa a denominar-se Faculdade Nacional de Ciências Econômicas, e funcionará como um centro nacional de ensino, em grau superior, de ciências econômicas e de ciências contábeis e atuariais, e bem assim de estudos e pesquisas nesses ramos dos conhecimentos científicos e técnicos.

\section{$[\ldots]$}

Art. 9o Ficam extintos a partir do ano escolar de 1946, o curso superior de administração e finanças e o curso de atuário, de que trata o Decreto no 20.158, de 30 de julho de 1931.

$\S 1$ o Os alunos ora matriculados num dos cursos de que trata este artigo, poderão conclui-lo segundo o plano de estudos ora revogado, ou adaptar-se ao correspondente curso definido pelo presente decreto-lei na série adequada aos conhecimentos adquiridos.

$\S 2^{\text {o }}$ Aos bacharéis em ciências econômicas, diplomados de acordo com a legislação ora revogada, são assegurados os mesmos direitos que correspondem aos bacharéis em ciências econômicas diplomados nos termos do presente decreto-lei.

$\S 3^{\text {o }}$ Aos contadores e atuários diplomados de acordo com a legislação anterior, são atribuídos os mesmos direitos que se assegurem aos bacharéis em ciências contábeis e atuariais diplomados nos termos do presente decretolei.

Embora o referido Decreto trate de um assunto que poderia ter certa importância para a história do ensino superior de Administração, no Brasil, na revisão bibliográfica para este artigo praticamente não foram encontrados registros sobre eventuais impactos dessa decisão quanto à carreira de profissionais de administração. Na mesma época, já em 1948, impulsionados pela forte influência dos Estados Unidos da América no pós-guerra, e como resultado de cooperação técnica com o Brasil e com o apoio das Organizações das Nações Unidas (ONU), representantes da FGV realizam várias visitas a universidades americanas com a intenção de buscar modelos para a "criação de uma escola destinada à formação de jovens administradores e à difusão da teoria da administração no país” (COELHO, 2006, p. 25).

Como resultado dessa cooperação técnica, em 15 de abril de 1952, a Fundação Getúlio Vargas 
criou a Escola Brasileira de Administração Pública - EBAP, no Rio de Janeiro, como a primeira escola de administração pública do Brasil e da América Latina. Além disso, vale destacar que a EBAP foi a responsável pela criação dos primeiros livros de administração no Brasil e a primeira instituição a usar o sistema de créditos e matrícula por disciplina no país (EBAPE, 2012). Dois anos depois, em 1954, tendo em vista que a cidade de São Paulo era considerada a maior representante das atividades econômicas e produtivas do Brasil, e com o objetivo de criar mão de obra qualificada para atender à demanda do setor produtivo, a FGV criou a Escola de Administração de Empresas de São Paulo - EAESP (ALCADIPANI e BERTERO, 2012; COELHO, 2006; NICOLINI, 2003a; ROMUALDO, 2012).

De acordo com Alcadipani e Bertero (2012), a EAESP foi fruto de um convênio firmado entre a Fundação Getúlio Vargas e os governos brasileiro e americano. A escola contou com a presença de um grupo de professores da Michigan State University (MSU) que, além de estruturar todas as atividades, também formaram o corpo docente do curso, passando seus conhecimentos e experiências para os alunos da escola brasileira. A presença dos professores estrangeiros se deu por doze anos. 0 modelo adotado contou com professores assistentes brasileiros que traduziam as aulas dos professores americanos e, dessa forma, foram treinados para assumirem, no futuro, as atividades docentes das disciplinas oferecidas.

A EAESP iniciou suas atividades em 1954 com um curso voltado ao público de executivos e empresários. Este foi o CIA - Curso Intensivo de Administração, com duração aproximada de 13 semanas em regime de tempo integral. [...] 0 curso era uma inovação no Brasil e marcava o início de atividades que posteriormente seriam designadas como Educação Executiva. A audiência que se buscava, formada por empresários e executivos, tinha como finalidade abrir caminho para administradores profissionais e também aproximação com uma comunidade da qual se esperava no futuro apoio financeiro para sustentar a escola (ALCADIPANI e BERTERO, 2012, p. 5).

A FGV foi designada também como um centro de treinamento e de intercâmbio. Dessa forma, foram concedidas muitas bolsas de estudo para que profissionais pudessem continuar seus estudos nos cursos de pós-graduação nas universidades americanas e para a formação de quadro docente próprio. Os bolsistas da EBAP eram recebidos na University of Southern California e os da Eaesp se dirigiam à Michigan State University (NICOLINI, 2003a). A partir da década de 1960, a FGV passou a ministrar cursos de Pós-Graduação nas áreas de Administração Pública e de Empresas. Em 2001, a EBAP ampliou o seu espectro para além da Administração Pública, passando a denominar-se EBAPE - Escola Brasileira de Administração Pública e de Empresas.

Após o suicídio de Vargas (1954), o Brasil teve três presidentes (Café Filho, Carlos Luz e Nereu Ramos) que cumpriram curtos períodos de mandato, até que foi eleito Juscelino Kubitschek, em 1956. O Brasil viveu um período de notável desenvolvimento econômico e relativa estabilidade política. Cada vez mais, era de fundamental importância haver profissionais capacitados para atender as exigências das organizações que se instalavam e se consolidavam em um período de mudanças crescentes na economia. Isto é, com a complexidade cada vez maior e o crescimento, em tamanho, das organizações, aumentava a demanda pela implementação de técnicas administrativas que pudessem contribuir para atender aos desafios que o momento exigia. Como consequência, os profissionais precisavam de treinamento para que pudessem executar diferentes funções dentro das organizações (NICOLINI, 2003a). 
Assim, além de criar as suas próprias escolas de Administração, a Fundação Getúlio Vargas imprimiu qualidade na formação de administradores públicos e privados e tornou-se um exemplo seguido no país, a partir de então, contribuindo para a consolidação dos cursos de Administração nos níveis de graduação e pós-graduação (NICOLINI e FISCHER, 2007).

Segundo Coelho (2006), a EBAP teve participação importante na regulamentação da profissão de Administrador. Após dez anos de existência e com cerca de 200 profissionais bacharéis formados em Administração Pública, professores e egressos da EBAP (que não tinham garantias para exercerem seu ofício) mobilizaram-se no sentido de institucionalizar a profissão de Administrador, uma vez que o mercado de trabalho era ocupado por bacharéis formados em economia e em direito. Com a promulgação do Decreto no 1.108 , de 30 de maio de 1962, o governo federal reconheceu o curso da EBAP e, dessa forma, abriu caminho para a regulamentação da profissão.

A redação do artigo único do referido decreto delibera que

é concedido reconhecimento ao curso de Administração Pública da Escola Brasileira de Administração Pública, mantida pela Fundação Getúlio Vargas e situada no Rio de Janeiro, Estado da Guanabara.

Em 1963, a Faculdade de Economia e Administração da Universidade de São Paulo (FEA-USP) passou a oferecer os cursos de Administração de Empresas e de Administração Pública.

A profissão de Administrador é regulamentada a partir da promulgação da Lei no 4.769, de 9 de setembro de 1965. No Capítulo II da referida lei, que trata do campo e da atividade profissional, há a descrição das atividades profissionais, a saber:

Art. $3^{\text {o }}$ - A atividade profissional do Administrador, como profissão liberal ou não, compreende:

a) elaboração de pareceres, relatórios, planos, projetos, arbitragens e laudos, em que se exija a aplicação de conhecimentos inerentes às técnicas de organização;

b) pesquisas, estudos, análises, interpretação, planejamento, implantação, coordenação e controle dos trabalhos nos campos de administração geral, como administração e seleção de pessoal, organização, análise, métodos e programas de trabalho, orçamento, administração de material e financeira, administração mercadológica, administração de produção, relações industriais, bem como outros campos em que estes se desdobrem ou aos quais sejam conexos;

c) exercício de funções e cargos de Administrador do Serviço Público Federal, Estadual, Municipal, Autárquico, Sociedades de Economia Mista, empresas estatais, paraestatais e privadas, em que fique expresso e declarado o título do cargo abrangido.

d) o exercício de funções de chefia ou direção, intermediária ou superior assessoramento e consultoria em órgãos, ou seus compartimentos, da Administração pública ou de entidades privadas, cujas atribuições envolvam principalmente, a aplicação de conhecimentos inerentes às técnicas de administração;

e) magistério em matérias técnicas do campo da administração e organização. 
Também foram criados o Conselho Federal e os Conselhos Regionais de Administração, com as seguintes finalidades:

Art. 20 - O Conselho Federal de Administração, com sede e foro em Brasília, Distrito Federal, terá por finalidade:

a) propugnar por uma adequada compreensão dos problemas administrativos e sua racional solução;

b) orientar e disciplinar o exercício da profissão de Administrador;

c) elaborar o seu regimento;

d) dirimir dúvidas suscitadas nos Conselhos Regionais;

e) examinar, modificar e aprovar os regimentos internos dos Conselhos Regionais;

f) julgar, em última instância, os recursos de penalidades impostas pelos Conselhos Regionais de Administração;

g) votar e alterar o Código de Deontologia Administrativa, bem como zelar pela sua fiel execução, ouvidos os Conselhos Regionais de Administração;

h) aprovar, anualmente, o orçamento e as contas da Autarquia;

i) promover estudos e campanhas em prol da racionalização administrativa do País.

$[\cdots]$

Art. 39 - Os Conselhos Regionais de Administração, com sede nas capitais dos Estados, Distrito Federal e territórios, terão por finalidade:

a) dar execução às diretrizes formuladas pelo Conselho Federal de Administração;

b) fiscalizar, na área da respectiva jurisdição, o exercício da profissão de Administrador;

c) organizar e manter o registro dos Administradores;

d) julgar as infrações e impor as penalidades referidas na Lei número 4.769, de 09 de setembro de 1965, e neste Regulamento;

e) expedir as carteiras profissionais dos Administradores;

f) elaborar o seu regimento para exame e aprovação pelo Conselho Federal de Administração;

g) colaborar com os governos Federal, Estaduais e Municipais, bem assim, com as empresas de economia mista e privadas no âmbito de suas finalidades e no propósito de manter elevado o prestígio profissional dos Administradores.

De acordo com o sítio do Conselho Federal de Administração - CFA (2012), em 1979 foi realizado um concurso nacional para a seleção de um símbolo que representasse os atributos e identificasse o CFA. A Figura 1 apresenta as etapas sequenciais das dobraduras do 
quadrado original até o símbolo vencedor, que ainda hoje representa o sistema CFA/CRA.

Figura 1: Dobradura do quadrado e o Símbolo do Sistema CFA/CRA.
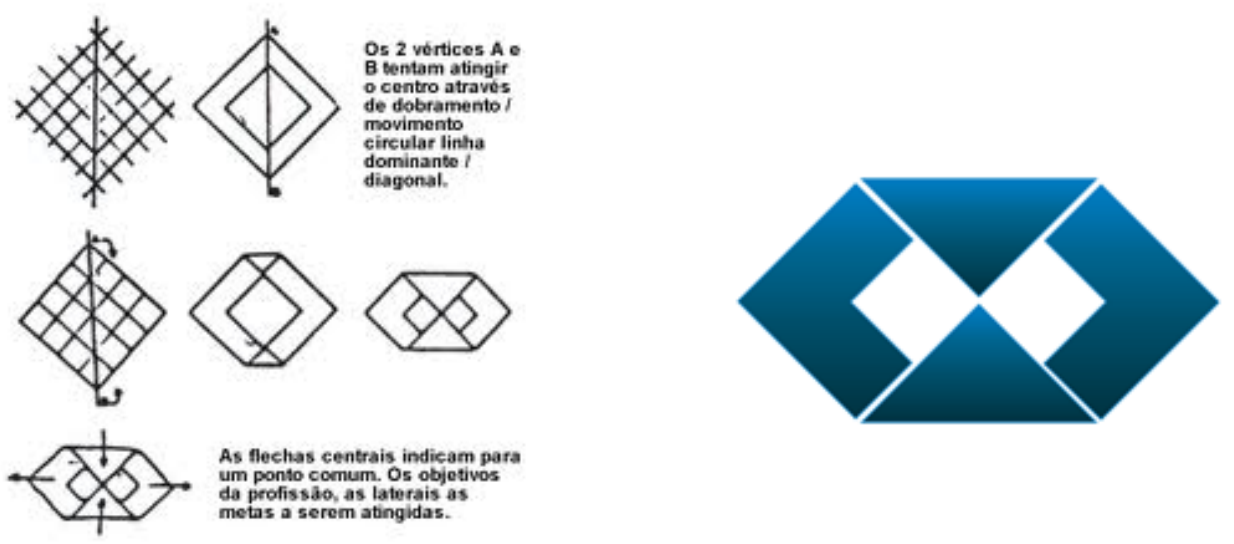

Fonte: Conselho Federal de Administração (2012)

O símbolo escolhido para identificar a profissão do Administrador tem a seguinte explicação pelos seus autores: "A forma aparece como intermediário entre o espírito e a matéria". Para Goethe o que está dentro (ideia), está também fora (forma) (CFA, 2012).

Conforme explicado pelo CRA/RJ (2012), os autores do símbolo são Marcos Jair Bento, Heloisa Hennemann e Cacilda da Silva Machado, que apresentam as seguintes justificativas para o sentido institucional do símbolo:

O quadro como ponto de partida: uma forma básica, pura, onde o processo de tensão de linhas é recíproco. Sendo assim, os limites verticais/horizontais entram em processo recíproco de tensão.

Uma justificativa para a profissão, que possui também certos limites em seus objetivos: organizar, dispor para funcionar, reunir, centralizar, orientar, direcionar, coordenar, arbitrar, relatar, planejar, dirigir, encaminhar os diferentes aspectos de uma questão para o objetivo comum.

0 quadrado é regularidade, possui sentido estático, quando apoiado em seu lado, e sentido dinâmico, quando apoiado em seu vértice (a posição escolhida).

As flechas indicam um caminho, uma meta, a partir de uma premissa, de um princípio de ação (o centro).

As flechas centrais se dirigem para um objetivo comum, baseado na regularidade, as laterais, as metas a serem atingidas.

\section{Os ciclos no ensino da administração}

Alguns autores consideram que, no ensino de Administração, ocorreram três ciclos bem definidos, relacionados aos currículos exigidos para a formação de seus profissionais (BRAGA et. al., 2011; PIZZINATO, 1999; SILVA e FISCHER, 2008). Tendo em vista o reconhecimento da profissão de Administrador, a partir da Lei no 4.769, em 8 de julho de 1966 foi emitido o Parecer 307/66, pelo Conselho Federal de Educação, estipulando o currículo mínimo do curso 
de graduação em administração, considerado então esse como o primeiro ciclo (CFA, 2012).

Esse parecer definiu o núcleo de disciplinas consideradas como o mínimo necessário para a boa formação profissional. Matemática, estatística, contabilidade, teoria econômica, economia brasileira, psicologia aplicada à administração, sociologia aplicada à administração, instituições de direito público e privado (incluindo noções de ética administrativa), legislação social, legislação tributária, teoria geral da administração, administração financeira e orçamento, administração de pessoal e administração de material formavam o currículo mínimo. Além dessas disciplinas, o aluno deveria escolher a disciplina de direito administrativo ou a disciplina de administração da produção e vendas para fechar a sua grade curricular. Finalmente, para complementar a sua formação o aluno deveria, ainda, realizar um estágio com duração de seis meses. A carga horária mínima estabelecida era de 2.700 horas e o formando recebia o título de Técnico em Administração (BRAGA et. al., 2011; CFA, 2012; PIZZINATO, 1999; SILVA e FISCHER, 2008).

0 currículo mínimo aprovado, em 1966, permaneceu vigente até 1993, quando foi definida uma reformulação a partir do Parecer 433/93, regulamentado pela Resolução no 02/93. Esta resolução traduziu os anseios de mudança pelos profissionais de Administração e trouxe um componente inovador, que é a possibilidade de criação de habilitações específicas ao curso de Administração. Era necessário que o currículo fosse ajustado aos avanços das ciências e tecnologias disponíveis, trazendo, inclusive, uma formação mais generalista (BRAGA et. al., 2011; NICOLINI, 2003b; SILVA e FISCHER, 2008).

A referida resolução, que caracteriza o segundo ciclo de mudanças, estruturou diferentes cargas horárias de acordo com as categorias de conhecimento, perfazendo assim um total de 3.000 horas, a saber: 720 horas $(24 \%$ do total) deveriam ser realizadas para a formação básica e instrumental; 1.020 horas (34\% do total) seriam realizadas para a formação profissional; 960 horas (32\% do total) com disciplinas eletivas e complementares; e 300 horas $(10 \%$ do total) relacionadas ao estágio supervisionado (PIZZINAT0, 1999; SOUZA, 2006). Além disso:

- A formação básica e instrumental contava com as seguintes disciplinas: economia, direito, matemática, estatística, contabilidade, filosofia, psicologia, sociologia e informática.

- Na formação profissional eram oferecidos os seguintes conteúdos: teorias da administração, administração mercadológica, administração da produção, administração de recursos humanos, administração financeira e orçamentária, administração de recursos materiais e patrimoniais, administração de sistemas de informação e organização, sistemas e métodos.

Uma nova edição da Lei de Diretrizes e Bases da Educação Nacional (LDB), promulgada em 20 de dezembro de 1998, estabeleceu o fim da vinculação entre a formação e o exercício profissional. Até essa data, para o exercício da profissão era necessário ter o diploma em mãos, daí a necessidade de se implementar um currículo mínimo (NICOLINI, 2000; SOUZA, 2006).

Liberado o ensino da exigência de formação obrigatória do profissional, aponta a nova LDB no sentido de assegurar maior flexibilidade e diversidade na organização de cursos e carreiras, atendendo à crescente heterogeneidade, tanto da formação prévia, como das expectativas e dos interesses dos alunos (NICOLINI, 2000, p. 29). 
A nova LDB leva o Conselho Nacional de Educação a promover mudanças nas diretrizes curriculares e todos os cursos de graduação passam a seguir as Diretrizes Curriculares Nacionais, determinadas pelo Parecer 776/97. Essas diretrizes ensejaram muitos debates dentro da área de Administração, na forma de seminários e outros eventos para analisar e discutir essas novas propostas. No entanto, somente em 2004, e baseado no Parecer 134/2003, foi que o Conselho Nacional de Educação aprovou as diretrizes curriculares para os cursos de graduação de Administração (SILVA e FISCHER, 2008; SOUZA, 2006).

A partir da Resolução no 1 do Conselho Nacional de Educação, de 2 de fevereiro de 2004, foram instituídas as Diretrizes Curriculares Nacionais do Curso de Graduação em Administração, em nível de Bacharelado, dando a orientação às instituições educacionais para a formação do projeto acadêmico e pedagógico do referido curso. No entanto, em 13 de julho de 2005, foi publicada a Resolução CNE/CES 4/05 que, em seu artigo no 12 revoga a Resolução CFE no 2, de 4 de outubro de 1993, bem como a Resolução CNE/CES no 1, de 2 de fevereiro de 2004. Esta mudança foi motivada, principalmente, por um novo entendimento relacionado à graduação de administração, sem a oferta de habilidades específicas. Essa resolução está em vigor até hoje, caracterizando o terceiro ciclo de mudanças na estrutura curricular para a formação de profissionais de administração.

Vale destacar que o artigo 4ํㅜㄹ da Resolução CNE/CES 4/05, propõe que o Curso de Graduação em Administração deve possibilitar a formação profissional que revele, pelo menos, as seguintes competências e habilidades:

I - reconhecer e definir problemas, equacionar soluções, pensar estrategicamente, introduzir modificações no processo produtivo, atuar preventivamente, transferir e generalizar conhecimentos e exercer, em diferentes graus de complexidade, o processo da tomada de decisão;

II - desenvolver expressão e comunicação compatíveis com o exercício profissional, inclusive nos processos de negociação e nas comunicações interpessoais ou intergrupais;

III refletir e atuar criticamente sobre a esfera da produção, compreendendo sua posição e função na estrutura produtiva sob seu controle e gerenciamento;

IV - desenvolver raciocínio lógico, crítico e analítico para operar com valores e formulações matemáticas presentes nas relações formais e causais entre fenômenos produtivos, administrativos e de controle, bem assim expressando-se de modo crítico e criativo diante dos diferentes contextos organizacionais e sociais;

V - ter iniciativa, criatividade, determinação, vontade política e administrativa, vontade de aprender, abertura às mudanças e consciência da qualidade e das implicações éticas do seu exercício profissional;

VI - desenvolver capacidade de transferir conhecimentos da vida e da experiência cotidianas para o ambiente de trabalho e do seu campo de atuação profissional, em diferentes modelos organizacionais, revelando-se profissional adaptável;

VII - desenvolver capacidade para elaborar, implementar e consolidar projetos em organizações; e 
VIII - desenvolver capacidade para realizar consultoria em gestão e administração, pareceres e perícias administrativas, gerenciais, organizacionais, estratégicos e operacionais.

Observa-se que as Diretrizes Curriculares Nacionais, em vigor para os cursos de graduação de Administração, permitem que as instituições de ensino superior possam elaborar projetos pedagógicos flexíveis e de acordo com as demandas de mercado e especificidades locais, incluindo novos conhecimentos na grade curricular, até então ainda não oferecidos. Ou seja, as instituições têm autonomia para definir seus projetos no sentido de formar um profissional de Administração de acordo com a demanda do mercado, aumentando a sua empregabilidade a partir de práticas modernas da administração.

\section{O papel da ANPAD}

Em 3 de dezembro de 1965, foi publicado o Parecer no 977 do Conselho Federal de Educação, sendo Newton Sucupira o seu relator. Esse parecer aborda, de maneira geral, um breve histórico sobre a pós-graduação e a sua importância, apresenta o exemplo dos Estados Unidos e o que se deveria pretender para o Brasil (FACHIN, 2006). No mesmo ano, dos 38 cursos de pós-graduação stricto sensu classificados no nível de mestrado e de doutorado, oito eram da área de Administração (CAPES, 2012; CRA/RJ, 2012).

Na década de 1970, no bojo do desenvolvimento econômico do chamado milagre brasileiro, da entrada de empresas multinacionais e de capital estrangeiro no país e, ainda, das demandas de titulação do corpo docente das universidades, aumentaram os cursos de pósgraduação (stricto sensu e lato sensu) em Administração. É nesse contexto que, em reunião realizada no dia 21 de dezembro de 1976, houve a aprovação do estatuto da ANPAD Associação Nacional dos Programas de Pós-Graduação em Administração, constituída por 9 programas de pós-graduação em Administração (COPPEAD/UFRJ, EBAP/FGV, EAESP/FGV, FEA/USP, PPGA/UFRGS, PPGA/UFPB, PUC/RJ, UFMG e UnB) e um de Ciências Contábeis (Programa de Ciências Contábeis da USP).

Nos Estatutos, previa-se, basicamente:

- Representar os interesses das instituições filiadas junto ao governo e entidades correlatas;

- "estabelecer um centro de informações e de demonstração a respeito de métodos de ensino, planos de pesquisas e fontes de recursos";

- Colaborar com instituições de ensino e pesquisa no sentido de prestar informações para "a montagem de Programas e cursos de pós-graduação em Administração ou Ciências Contábeis";

- "promover a cooperação e o intercâmbio entre as instituições filiadas";

- "publicar e promover a publicação de livros, revistas e artigos";

- "promover e realizar congressos, seminários e reuniões de interesse dos membros da ANPAD" (FACHIN, 2006, p. 32-33).

Ao longo desses últimos 36 anos, a ANPAD vem agregando distintas posições teóricas nas ciências administrativas contábeis e afins, sendo uma importante arena para debates acadêmicos e de vivência social. Com o objetivo de estimular discussões entre professores, pesquisadores e alunos de pós-graduação, a ANPAD conta hoje com onze divisões acadêmicas, quais sejam: ADI - Administração da Informação; APB - Administração Pública; CON Contabilidade; EOR - Estudos Organizacionais; EPQ - Ensino e Pesquisa em Administração e Contabilidade; ESO - Estratégia em Organizações; FIN - Finanças; GCT - Gestão de Ciência, 
Tecnologia e Inovação; GOL - Gestão de Operações e Logística; GPR - Gestão de Pessoas e Relações de Trabalho; e MKT - Marketing (ANPAD, 2012).

Hoje, a ANPAD congrega 91 Programas Associados Efetivos (com direito a voz e voto nas Assembleias Gerais), um Programa Associado Observador (com direito a voz durante as Assembleias) e um grande número de Associados Individuais, que se afiliam a uma ou mais Divisões Acadêmicas, participando das respectivas atividades e eventos. Além disso, ela promove dez eventos acadêmicos: AIB - Annual Meeting; EnADI - Administração de Sistemas de Informação; EnAnpad - Encontro da Anpad; EnAPG - Encontro de Administração Pública e Governança; EnEPQ - Ensino e Pesquisa em Administração e Contabilidade; EnEO - Divisão de Estudos Organizacionais; EnGPR - Divisão Acadêmica de Gestão de Pessoas e Relações de Trabalho; EMA - Divisão de Estudos em Marketing; Simpósio - Divisão de Gestão de Ciência, Tecnologia e Inovação; e 3Es - Divisão Acadêmica de Estudos em Estratégia. (ANPAD, 2012)

A ANPAD é uma das maiores associações do gênero no mundo. Na 30a edição do Encontro da ANPAD, que ocorreu em 2006, mais de 3.000 trabalhos foram submetidos e cerca de 850 foram selecionados para serem apresentados. "Tudo isso indica uma associação voltada primordialmente para a pesquisa, a publicação e a difusão da produção científica" (BERTERO, 2007, p. 9). Especificamente, a ANPAD tem uma divisão que se preocupa com o ensino, chamada de Divisão de Ensino e Pesquisa em Administração e Contabilidade - EPQ. Essa preocupação é corroborada por Bertero (2007, p. 9):

A capacitação docente tende a ser questão de importância crescente em função da redução na idade e da menor experiência profissional de muitos dos atuais alunos de cursos de mestrado e doutorado. Atualmente, a idade tende a reduzir-se especialmente para os programas de doutorado. Há uma tendência de estagnação relativa dos mestrados acadêmicos e de expansão dos mestrados profissionais. Diante disso, os doutorados sobressaem como o único curso puramente acadêmico no stricto sensu. Isso levará a que se saia da graduação diretamente para o doutorado. 0 resultado serão classes de doutorandos bem mais jovens o que as atuais.

\section{Instituições de Ensino Superior (IES) brasileiras}

A Constituição de 1988 incluiu vários artigos relacionados à educação, dando origem a leis que hoje regulam o ensino superior. Com isso, a partir dos anos 1990, foi necessário flexibilizar e ampliar o sistema de educação superior e melhorar os processos de avaliação com foco no aumento da qualidade da educação, buscando atender à demanda crescente do mercado por profissionais qualificados.

O Estado, mesmo não tendo exclusividade, tem papel fundamental na prestação do serviço de educação superior, incluindo a obrigação de regular todas as atividades relacionadas ao tema. De acordo com Cezne (2006, p. 9),

o que se busca é estabelecer uma regulamentação jurídica adequada, a fim de que a colaboração com os entes não-estatais não signifique falta de controle e irresponsabilidade do Estado na prestação dos serviços, que não são propriamente atividades econômicas, mas visam a implementação de relevantes direitos sociais, a exemplo da educação. Ressalte-se que a colaboração nesse sentido encontra respaldo constitucional, e na verdade o setor não estatal representa hoje numericamente a maior parte do ensino superior. Seria uma forma de garantir a prestação da atividade com qualidade, uma obrigação dúplice do Estado, neste caso especificamente da União, seja 
como prestador, seja como fiscal da prestação da educação pelas entidades não estatais.

Além disso, conforme o artigo 43 da Lei de Diretrizes e Bases da Educação Nacional (Lei no 9.394, de 20 de dezembro de 1996), a educação superior tem por finalidade:

I - estimular a criação cultural e o desenvolvimento do espírito científico e do pensamento reflexivo;

II - formar diplomados nas diferentes áreas de conhecimento, aptos para a inserção em setores profissionais e para a participação no desenvolvimento da sociedade brasileira, e colaborar na sua formação contínua;

III - incentivar o trabalho de pesquisa e investigação científica, visando o desenvolvimento da ciência e da tecnologia e da criação e difusão da cultura, e, desse modo, desenvolver o entendimento do homem e do meio em que vive;

IV - promover a divulgação de conhecimentos culturais, científicos e técnicos que constituem patrimônio da humanidade e comunicar o saber através do ensino, de publicações ou de outras formas de comunicação;

$\mathrm{V}$ - suscitar o desejo permanente de aperfeiçoamento cultural e profissional e possibilitar a correspondente concretização, integrando os conhecimentos que vão sendo adquiridos numa estrutura intelectual sistematizadora do conhecimento de cada geração;

VI - estimular o conhecimento dos problemas do mundo presente, em particular os nacionais e regionais, prestar serviços especializados à comunidade e estabelecer com esta uma relação de reciprocidade;

VII - promover a extensão, aberta à participação da população, visando à difusão das conquistas e benefícios resultantes da criação cultural e da pesquisa científica e tecnológica geradas na instituição.

Com o objetivo de atender essas demandas, a educação superior brasileira está organizada a partir de instituições de ensino superior (IES), que podem ser públicas ou privadas, com diversos níveis de alcance ou de especialização, tendo em vista as intenções institucionais de cada IES. As instituições públicas de ensino são aquelas mantidas pelo poder público, em nível federal, estadual ou municipal. Essas instituições são financiadas pelo Estado e não cobram matrícula ou mensalidade.

Já as IES privadas são administradas por pessoas físicas ou jurídicas de direito privado, com ou sem finalidade de lucro. As principais fontes de financiamento de suas operações provem do pagamento de mensalidades por parte de seus respectivos alunos, porém podem envolver outras linhas de obtenção de recursos. As instituições privadas sem fins lucrativos são entendidas como sendo as comunitárias, que incluem em sua entidade mantenedora representantes da comunidade; as confessionais, que atendem a determinada orientação confessional e ideológica; e as filantrópicas, que prestam serviços à população, em caráter complementar às atividades do Estado. As instituições comunitárias, confessionais e filantrópicas usufruem de isenções fiscais e, portanto, os resultados financeiros obtidos de suas atividades devem ser reinvestidos nelas próprias, não havendo distribuição de lucros.

O MEC (2012) apresenta o sistema educacional de ensino superior no Brasil formado, de acordo com sua organização acadêmica, por quatro tipos de Instituições de Ensino Superior 
(IES), a saber: universidades, centros universitários, faculdades e os institutos federais de educação tecnológica. Os centros universitários são definidos como instituições de ensino superior pluricurriculares, abrangendo uma ou mais áreas do conhecimento, e que se caracterizam pela excelência do ensino oferecido, comprovada pela qualificação do seu corpo docente e pelas condições de trabalho acadêmico oferecidas à comunidade escolar. Essas instituições, uma vez credenciadas, têm autonomia para criar, organizar e extinguir, em sua sede, cursos e programas de educação superior.

As universidades são caracterizadas pela não dissociação das atividades de ensino, de pesquisa e de extensão. Elas são instituições pluridisciplinares de formação dos quadros profissionais de nível superior, de pesquisa, de extensão e de domínio e cultivo do saber humano, que se caracterizam por: I - produção intelectual institucionalizada mediante o estudo sistemático dos temas e problemas mais relevantes, tanto do ponto de vista científico e cultural, quanto regional e nacional; II - um terço do corpo docente, pelo menos, com titulação acadêmica de mestrado ou doutorado; III - um terço do corpo docente em regime de tempo integral. Elas têm autonomia administrativa incluindo a gestão dos recursos financeiros e do patrimônio institucional, além da autonomia científica e didática.

As faculdades caracterizam-se por oferecer propostas curriculares em mais de uma área do conhecimento, que devem ser organizadas sob o mesmo comando e com um regimento unificado, com a finalidade de formar profissionais de nível superior, podendo ministrar cursos nos vários níveis (graduação, pós-graduação e extensão) e modalidades do ensino. É importante destacar que a faculdade tem duas conotações: a primeira é a de uma IES que não apresenta autonomia para conferir títulos e diplomas, os quais devem ser registrados por uma Universidade, bem como aquela que não tem a função de promover a pós-graduação. A segunda conotação é aplicada como referência a unidades orgânicas de uma Universidade instalada como, por exemplo, Faculdade de Administração, Ciências Contábeis e Turismo da Universidade Federal Fluminense.

Finalmente, existem os Institutos Federais de Educação, Ciência e Tecnologia (IFS) e os Centros Federais de Educação Tecnológica (CEFETS), que constituem a atual Rede Federal de Educação Profissional, Científica e Tecnológica, criada pela Lei no 11.892, de 29 de dezembro de 2008. A finalidade dessas instituições de educação superior é qualificar profissionais em cursos superiores de educação tecnológica para os diversos setores da economia e realizar pesquisa e desenvolvimento tecnológico de novos processos, produtos e serviços, em estreita articulação com os setores produtivos e a sociedade, oferecendo, inclusive, mecanismos para a educação continuada. Stallivieri (2012) lembra que somente universidades têm a responsabilidade pela pesquisa associada ao ensino. Um dos fatores preponderantes relaciona-se aos altos custos envolvidos com o desenvolvimento de pesquisa, o que limita o investimento de outras IES em estimular pesquisa associadas ao ensino.

De forma geral, com relação à formação, a educação superior abrange os cursos de graduação e pós-graduação, que podem ser stricto sensu e lato sensu. Na graduação o aluno pode optar por bacharelado, licenciatura ou formação tecnológica. Segundo o MEC (2012), o bacharelado é o curso superior que confere ao diplomado competências em determinado campo do saber para o exercício de atividade acadêmica ou profissional. A licenciatura, por sua vez, prepara o estudante para ser professor na educação básica, e os cursos superiores de formação tecnológicas conferem ao diplomado competências para atuar em áreas profissionais específicas, caracterizadas por eixos tecnológicos, com o grau de tecnólogo.

Os cursos de pós-graduação são abertos a candidatos diplomados em cursos de graduação e 
que atendam às exigências das instituições de ensino. Esses cursos abrangem os programas de mestrado e doutorado, considerados cursos de pós-graduação stricto sensu, e cursos de especialização, considerados pós-graduação lato sensu. A pós-graduação lato sensu confere certificado e a pós-graduação stricto sensu confere diploma.

\section{O papel da CAPES}

Em linha com o desenvolvimento do país no segundo governo Vargas, o Decreto no 29.741 , de 11 de Julho de 1951, instituiu uma comissão para promover a Campanha Nacional de Aperfeiçoamento de Pessoal de Nível Superior (CAPES), com o objetivo de assegurar a existência de profissionais em quantidade e qualidade suficientes para atender às necessidades dos empreendimentos públicos e privados em curso no país.

Nessa ocasião, o crescimento da industrialização e a complexidade da administração pública provocaram a necessidade em formar especialistas e pesquisadores nas mais diversas áreas. Durante os primeiros anos, a CAPES trabalhou na sua estruturação e, como estratégia básica, decidiu fazer articulações institucionais com o setor privado, principalmente com a indústria, e também com o setor público, pois tinha a intenção de atender às necessidades das organizações como um todo (FERREIRA e MOREIRA, 2012).

Em 1953, foi criado o Programa Universitário, principal linha de atuação da CAPES junto às universidades e institutos de ensino superior, pelo qual todos os projetos teriam que contar com um professor sênior para dinamizar as atividades acadêmicas e estimular o intercâmbio entre instituições. Na sequência, gradativamente foram sendo oferecidas bolsas de estudo de pós-graduação, sendo hoje a atividade de maior peso dentro da instituição (CAPES, 2012).

Em 1965, foram então classificados 27 cursos no nível de mestrado e 11 no nível de doutorado, perfazendo um total de 38 cursos de pós-graduação stricto sensu. Em 1981, o Decreto $\mathrm{n}^{\circ} 86.791$ reconhece a CAPES como órgão responsável pela elaboração do Plano Nacional de Pós-Graduação Stricto Sensu. E como Agência Executiva do Ministério da Educação e Cultura junto ao sistema nacional de Ciência e Tecnologia, à CAPES cabe elaborar, avaliar, acompanhar e coordenar as atividades relativas ao ensino superior.

Em 1995, a Capes passa por uma reestruturação, fortalecida como instituição responsável pelo acompanhamento e avaliação dos cursos de pós-graduação stricto sensu brasileiros. Naquele ano, o sistema de pós-graduação ultrapassa a marca dos mil cursos de mestrado e dos 600 de doutorado, envolvendo mais de 60 mil alunos (CAPES, 2012).

\section{O sistema superior de educação}

De acordo com o censo da educação superior realizado em 2011, pelo Instituto Nacional de Estudos e Pesquisas Educacionais Anísio Teixeira (INEP), vinculado ao Ministério da Educação (INEP, 2012), o número de matrículas nas instituições de ensino superior chegou a quase 7 milhões, sendo cerca de 5 milhões em instituições privadas e 2 milhões em IES públicas. O Brasil tinha 6.739.689 estudantes matriculados em 30.616 cursos de Graduação, dos quais 1.032.936 pessoas em universidades públicas federais. Na pós-graduação, eram 213.611 matrículas, perfazendo um total de matrículas igual a 6.953.300. O Gráfico 1 apresenta o crescimento do número de matrículas de graduação, desde 1980 a 2011, considerando a esfera administrativa pública e privada. No período 2010-2011, a matrícula cresceu $7,9 \%$ na rede pública e $4,8 \%$ na rede privada. 
Gráfico 1: Evolução da matrícula de graduação por dependência administrativa

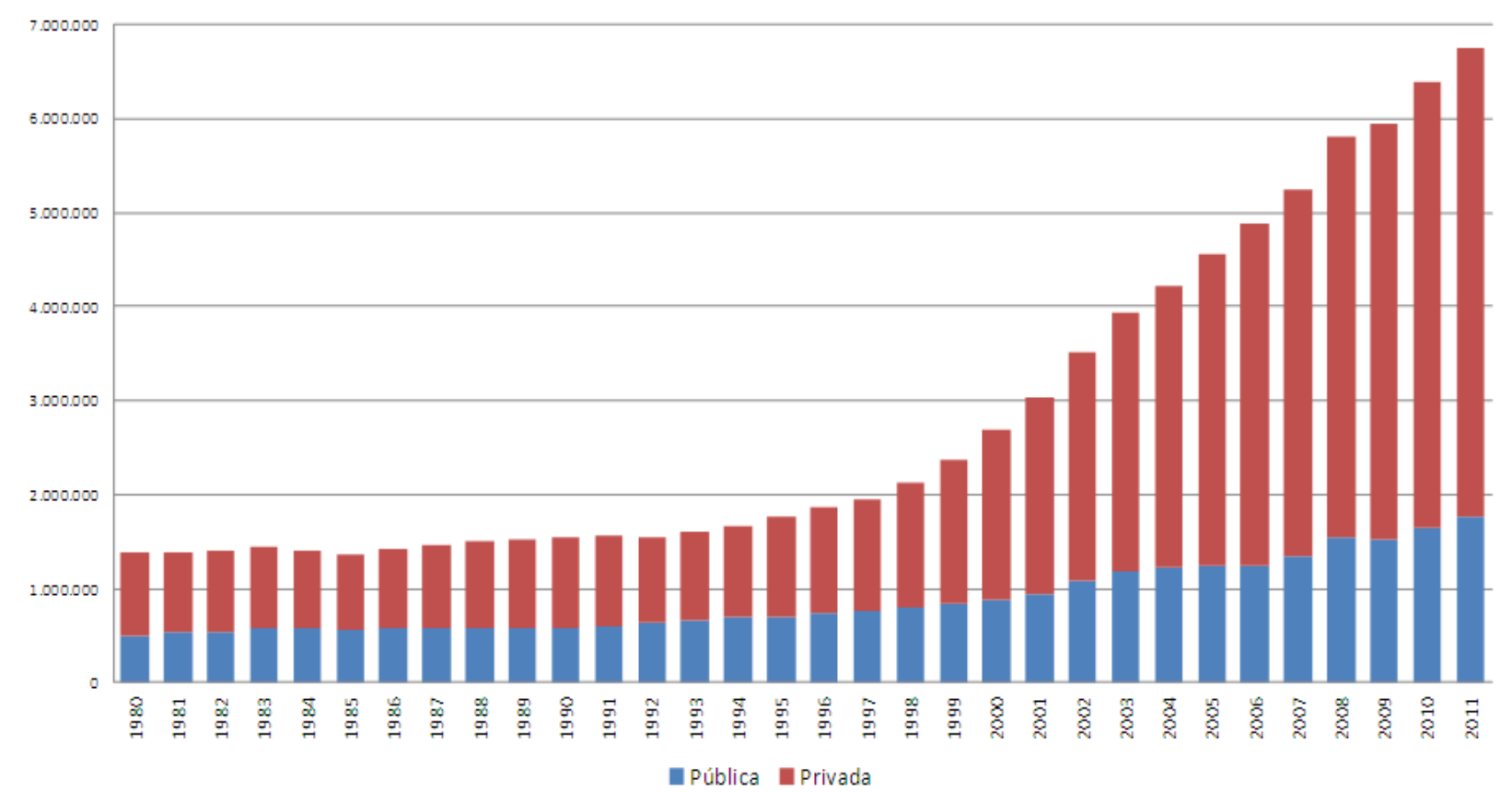

Fonte: Censo de educação superior (INEP, 2012)

Observa-se, ainda, um crescimento acentuado na participação das IES particulares, a partir de meados da década de 1990, período no qual o Brasil adotou, de maneira acentuada, políticas públicas com foco no desenvolvimento econômico e tecnológico do país. O censo de 2011 mostra que as IES privadas têm uma participação de quase $74 \%$ no total de matrículas de graduação, ficando cerca de $26 \%$ sob a responsabilidade do poder público.

Dado que a ampliação das vagas nas universidades públicas, aliada às medidas de racionalização econômica e administrativa, tais como a unificação do vestibular ou a criação de um ciclo básico de estudos, não era suficiente para atender ao volume da demanda, o governo passou a estimular o crescimento da oferta privada (MENDONÇA, 2000, p. 148).

Das instituições de ensino superior mantidas pelo poder público, 58\% são federais, como pode ser verificado no Gráfico 2 .

Gráfico 2: Distribuição das instituições de ensino superior públicas por ente federativo.

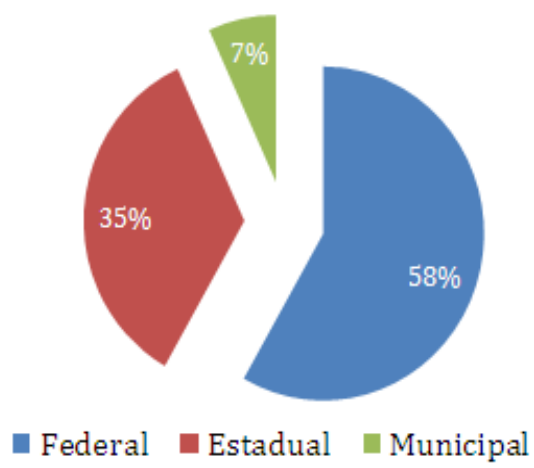

Fonte: Censo de educação superior (INEP, 2012) 
Quanto ao grau acadêmico, constata-se pelo Gráfico 3 que quase $70 \%$ das matrículas encontram-se nos cursos de bacharelado, contribuindo, dessa forma, para a formação científica ou humanística do cidadão, em um determinado campo do saber, de tal forma a exercer atividade profissional, acadêmica ou cultural.

Gráfico 3: Distribuição das matrículas de graduação por grau acadêmico.

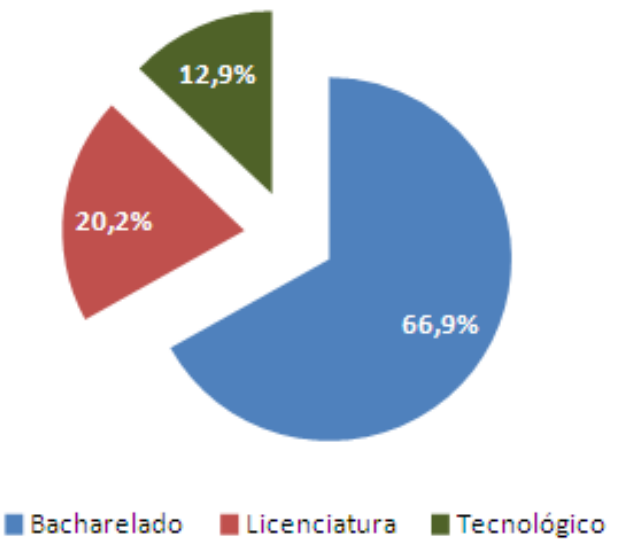

Fonte: Censo de educação superior (INEP, 2012)

Com relação aos tipos de organização acadêmica, os dados do INEP (2012) mostram que, embora as universidades representem somente $8 \%$ do total das instituições de ensino superior, elas são responsáveis por quase $54 \%$ de todas as matrículas de graduação. Na Tabela 1 é possível verificar as quantidades de instituições e de matrícula de graduação pelas organizações acadêmicas em nível superior.

Tabela 1: Instituições de ensino superior e matrículas na graduação - Brasil 2011.

\begin{tabular}{lrrr}
\hline \multicolumn{1}{c|}{ Organização acadêmica } & Instituições & Matrícula de graduação \\
\hline Total & 2.365 & 6.739 .689 \\
& $100,0 \%$ & $100,0 \%$ \\
\hline Universidades & 190 & 3.632 .373 \\
\hline Centros Universitários & $8,0 \%$ & $53,9 \%$ \\
\hline Faculdades & 131 & 921.019 \\
\hline IFs e Cefets & $5,5 \%$ & $13,7 \%$ \\
& 2.004 & 2.084 .671 \\
\hline
\end{tabular}

Fonte: Censo de educação superior (INEP, 2012)

\section{Os cursos de Administração}

Conforme já citado nesse artigo, até 1960 existiam dois cursos específicos e dedicados ao 
ensino da Administração no Brasil: o da EBAP, no Rio de Janeiro, (foco em administração pública) e da EAESP, em São Paulo, (foco na administração de empresas), ambas as escolas da Fundação Getúlio Vargas.

Daquela época para cá, muita coisa mudou. A Tabela 2 apresenta a evolução dos cursos de graduação, após 1960, contendo a quantidade de IES, matrículas e concluintes. É possível observar que houve grande expansão em número de IES oferecendo cursos de graduação, após 1990.

Tabela 2: Resumo da evolução dos Cursos de Administração no Brasil

\begin{tabular}{|c|c|c|c|}
\hline Ano & IES & Matrículas & Concluintes \\
\hline 1960 & 31 & $\mathrm{~N} / \mathrm{I}$ & $\mathrm{N} / \mathrm{I}$ \\
\hline 1970 & 164 & 66.829 & 5.276 \\
\hline 1980 & 247 & 134.742 & 21.746 \\
\hline 1990 & 320 & 174.330 & 22.394 \\
\hline 2000 & 821 & 338.789 & 35.658 \\
\hline 2002 & 1.158 & 493.104 & 54.656 \\
\hline 2003 & 1.710 & 576.305 & 64.792 \\
\hline 2004 & 2.048 & 641.455 & 88.466 \\
\hline
\end{tabular}

Fonte: Adaptado do Manual do Administrador (2012)

Nicolini (2003a, p. 47) acrescenta que

um fator importante para a evolução desmedida do crescimento da graduação em Administração era que a abertura apresentava-se vantajosa, uma vez que poderiam ser estruturados sem muitos dispêndios financeiros [...], pois não eram necessários investimentos vultosos em laboratórios sofisticados e nem em qualquer outro refinamento tecnológico.

Os dados do censo de 1998, realizado pelo INEP (2012), mostram que, no ano anterior, os cursos de Administração formaram 31.630 alunos. Em 1998, o total de inscritos em vestibulares para Administração chegou a 99.338, enquanto o total de matriculados em cursos reconhecidos foi de 257.408. Os dados do censo de 2003, disponibilizados pelo INEP (2012), mostram que o número de matrículas no curso de Administração alcançou a primeira posição entre todos os cursos pesquisados, ultrapassando em quase $11 \%$ o do curso de Direito, como segundo colocado. Na comparação dos dados de 1998 com os dados de 2003 verifica-se o crescimento extraordinário que os cursos de graduação tiveram em apenas cinco anos. As matrículas em Administração tiveram um crescimento de 119\%. Os cursos de Administração formaram 63.688 alunos em 2003 (INEP, 2012).

De acordo com o censo da educação superior 2011, realizado pelo INEP (2012), o curso de Administração continua apresentado os maiores números de matrículas, seguido do curso de direito e pedagogia. Comparando-se os dados de 2003 com os dados de 2011, pode-se constatar que, embora menos acentuadamente do que o ocorrido entre 1998 e 2003, manteve-se a tendência ao crescimento no número de matrículas em Administração. Em 
2011, a quantidade de alunos que concluíram o curso de Administração foi de 126.336, passando a formar, a partir de então, o maior número de profissionais de todos os cursos em nível de graduação no Brasil. Além disso, constata-se que o ensino de administração foi responsável por mais de $12 \%$ do total de matrículas no sistema educacional, como um todo.

No Gráfico 4 é possível constatar visualmente a evolução dos números de matrículas nos cursos de Administração, bem como o crescimento do número de profissionais formados em todos as Instituições de Ensino Superior (IES) nos Cursos de Administração.

Gráfico 4: Evolução de matrículas e concluintes nos cursos de Administração

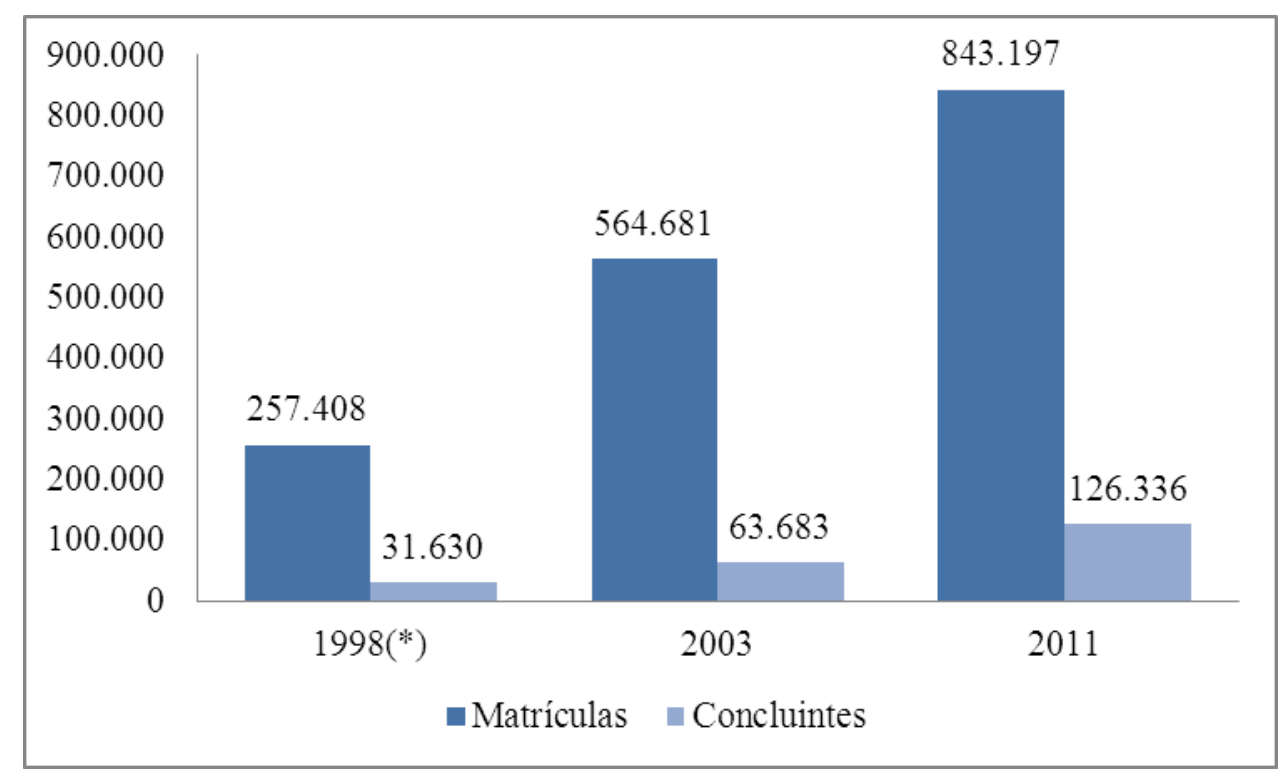

Fonte: Adaptado do INEP (2012)

(*) Os dados de concluintes são relativos ao ano de 1997.

\section{Considerações finais}

Este artigo teve a intenção de contribuir para a melhor compreensão do histórico que envolveu e ainda envolve o ensino de Administração no Brasil, buscando auxiliar no processo de recuperação de informações, na evolução de novas pesquisas para os temas abordados e no melhor entendimento dos fatores determinantes e mudanças ocorridas ao longo do tempo (PELEIAS et.al., 2007).

Ao discorrer sobre tantos fatos e informações, ao longo deste artigo, procurou-se mostrar a evolução dos cursos de Administração e o seu ensino, no Brasil. Os autores acham importante resgatar a afirmação de Nicolini (2003a, p. 52), quando afirma que "a demanda por administradores sempre acompanhou a estruturação econômica do país, relacionando-se com os momentos históricos desse processo até os dias de hoje".

0 artigo ressaltou que, até o ano de 1997, o sistema de ensino superior contava com menos de 2 milhões de matrículas sendo que, de 1998 a 2011, houve crescimento bastante acelerado, chegando a quase 7 milhões de matrículas, em 2011, 74\% delas em instituições de ensino superior (IES) privadas (INEP, 2012). Destaca-se que os cursos de administração significaram, em 2011, 12\% do total de matrículas do sistema superior de educação, sendo esta a área com 
o maior número de alunos inscritos, chegando a mais de 840 mil matrículas (INEP, 2012).

Tendo esses dados em mente, vale refletir sobre o que Bertero (2007) afirma, a saber:

Em nosso país, a área de Administração nos coloca em meio a uma situação de massificação, implicando mudanças nos objetivos da universidade, no perfil do alunado e consequentemente nas competências exigidas do professor. 0 aluno que hoje se encontra nas salas de aula é muito diferente do que era encontrado há não muito tempo. Mesmo professores jovens que começam a lecionar cinco ou 10 anos após a conclusão de seu curso de graduação experimentam o chamado "choque de gerações", que se reflete nas atitudes, expectativas e na maneira de entender a universidade e um curso superior.

Esse artigo quis desenvolver uma perspectiva sobre a disciplina de Administração, considerando sua evolução de forma cronológica e factual, na intenção de facilitar a leitura e o entendimento. Não há como exaurir os temas levantados, uma vez que são extensos e apresentam situações que se imbricam com várias mudanças econômicas, políticas e sociais.

Fica, como expressão final dos autores, o estímulo a que outros pesquisadores avancem nesse levantamento e agreguem novas referências para um melhor entendimento da Administração, sua exegese, o ensino e as possibilidades futuras. Haverá novo ciclo de mudança? Quando? E como está a qualidade dos cursos de Administração no Brasil?

\section{Referências bibliográficas}

ALCADIPANI, Rafael e BERTERO, Carlos Osmar. Uma escola norte-americana no ultramar? Uma historiografia da Escola de Administração de Empresas de São Paulo da Fundação Getúlio Vargas. XXXVI Encontro da ANPAD. Rio de Janeiro/RJ, 2012.

ASSOCIAÇÃO NACIONAL DE PÓS-GRADUAÇÃO E PESQUISA EM ADMINISTRAÇÃO - ANPAD. Disponível em http://www.anpad.org.br/index.php. Acesso em 30 nov. 2012.

BERTERO, Carlos Osmar. A docência numa universidade em mudança. Cadernos EBAPE.BR, v. V, Edição Especial, 2007.

BIELINSKI, Alba Carneiro. Educação profissional no século XIX - Curso Comercial do Liceu de Artes e Ofícios: um estudo de caso. Disponível em http://www.senac.br/BTS/263/boltec263e.htm. Acesso em 19 nov. 2012.

BRAGA, Gustavo B. et. al. Análise da formação curricular dos cursos de administração oferecidos por instituições federais da Zona da Mata Mineira à luz da resolução CNE/CES no 4, de 13 de julho de 2005. Revista de Administração em Diálogo, v. 13, n. 3, set./out./nov./dez., p. 56-68, 2011.

BRASIL. Decreto no 29.741, de 11 de Julho de 1951. Institui uma comissão para promover a campanha nacional de aperfeiçoamento de pessoal de nível superior.

BRASIL. Parecer no 977 CES, de 3 de dezembro de 1965. Definição dos cursos de PósGraduação.

BRASIL. Decreto no 20.158, de 30 de junho de 1931. Organização do ensino comercial e criação do curso superior de administração e finanças.

BRASIL. Ministério da Educação. Conselho Nacional de Educação. Câmara de Educação 
Superior. Resolução no 1, de 2 de fevereiro de 2004. Institui as Diretrizes Curriculares Nacionais do Curso de Graduação em Administração, bacharelado, e dá outras providências.

BRASIL. Ministério da Educação. Conselho Nacional de Educação. Câmara de Educação Superior. Resolução no 4, de 13 de julho de 2005. Institui as Diretrizes Curriculares Nacionais do Curso de Graduação em Administração, bacharelado, e dá outras providências.

CEZNE, Andrea Nárriman. 0 direito à educação superior na Constituição Federal de 1988 como direito fundamental. Revista do Centro de Educação, v. 31, n. 1, 2006.

COELHO, Fernando de Souza. Educação superior, formação de administradores e setor público: um estudo sobre o ensino de administração pública - em nível de graduação - no Brasil. Tese. EAESP-FGV, 2006.

COELHO, Fernando de Souza, NICOLINI, Alexandre Mendes. Uma Contribuição à História do Ensino de Graduação em Administração Pública no Brasil (1952-1994): proposta de periodização e análise de um dos estágios de construção. XXXIV Encontro da ANPAD. Rio de Janeiro/RJ, 2010.

CONSELHO FEDERAL DE ADMINISTRAÇÃO - CFA. Disponível em http://www2.cfa.org.br/administrador/. Acesso em 24 nov. 2012.

CONSELHO REGIONAL DE ADMINISTRAÇÃO DA BAHIA - CRA/BA. Disponível em http://www.cra-ba.org.br/Pagina/58/Historico-dos-Cursos-de-Administracao-no-Brasil.aspx. Acesso em 30 nov. 2012.

CONSELHO REGIONAL DE ADMINISTRAÇÃO DO RIO DE JANEIRO - CRA/RJ. Disponível em http://www.cra-rj.org.br/site/quem/simbolos.asp. Acesso em 24 nov. 2012.

COORDENAÇÃO DE APERFEIÇOAMENTO DE PESSOAL DE NÍVEL SUPERIOR - CAPES. Disponível em http://www.capes.gov.br/duvidas-frequentes/62-pos-graduacao/3019-quaisos-tipos-de-pos-graduacao-existem-e-quais-as-suas-diferencas. Acesso em 20 nov. 2012.

CPDOC - Centro de Pesquisa e Documentação de História Contemporânea do Brasil. Disponível em http://cpdoc.fgv.br/producao/dossies/AEraVargas1/anos3745/PoliticaAdministracao/FGV. Acesso em 20 nov. 2012.

CUNHA, Luiz Antônio. A universidade temporã. 3. ed. São Paulo: UNESP, 2007.

EBAPE - Escola de Administração. Disponível em http://ebape.fgv.br/quem-somos/historia. Acesso em 24 nov. 2012.

EGOSHI, Koiti. ESAN - Escola Superior de Administração de Negócios: A Primeira Escola de Administração do Brasil e da América Latina. Disponível em http://www.cienciadaadministracao.com.br/ESAN.htm. Acesso em 19 nov. 2012.

E-MEC. Disponível em http://emec.mec.gov.br/. Acesso em 19 nov. 2012.

FACHIN, Roberto Costa. Construindo uma Associação Científica: trinta anos da ANPAD memórias, registros e desafios. Porto Alegre: [s.n.], 2006.

FÁVERO, Maria de Lourdes de A. A universidade do Brasil: um itinerário marcado de lutas. Revista Brasileira de Educação, n. 10, jan./abr., 1999. 
FÁVERO, Maria de Lourdes de A. A universidade no Brasil: das origens à Reforma Universitária de 1968. Educar, Curitiba, n. 28, p. 17-36, 2006.

FECAP - Fundação Escola de Comércio Álvares Penteado. Disponível em http://www.fecap.br/novoportal/historia_fecap.php?p=3. Acesso em 19 nov. 2012.

FEI - FUNDAÇÃO EDUCACIONAL INACIANA. Disponível em http://www.fei.org.br/PadreSaboiaMedeiros.aspx. Acesso em 19 nov. 2012.

FERREIRA, Marieta de M. e PINTO, Surama Conde Sá. A crise dos anos 20 e a Revolução de trinta. Rio de Janeiro: CPDOC, 2006. Disponível em http://cpdoc.fgv.br/producao_intelectual/arq/1593.pdf. Acesso em 30 nov. 2012.

FERREIRA, Marieta de M. e MOREIRA, Regina da L (org.). Capes, 50 anos. Disponível em http://cpdoc.fgv.br/producao_intelectual/arq/1319.pdf. Acesso em 30 nov. 2012.

GIL, Antonio Carlos. Como elaborar projetos de pesquisa. 4. ed. São Paulo: Atlas, 2002.

INSTITUTO NACIONAL DE ESTUDOS E PESQUISAS EDUCACIONAIS ANÍSIO TEIXEIRA - INEP. Palestra resultado do censo da educação superior 2011. Disponível em http://portal.inep.gov.br/web/censo-da-educacao-superior/encontro-nacional. Acesso em 20 nov. 2012.

MANUAL DO ADMINISTRADOR. Disponível em http://www2.cfa.org.br/administrador/. Acesso em 30 nov. 2012.

MARCONI, Mariana de Andrade e LAKATOS, Eva Maria. Fundamentos de metodologia científica. 7. ed. São Paulo: Atlas, 2010.

MARTINS, Paulo Emílio Matos. O Brasil versus a Universidade. Cadernos EBAP, no 51 - maio de 1990.

MENDONÇA, Ana Waleska P. C. A universidade no Brasil. Revista Brasileira de Educação. n. 14, mai./ago., 2000.

MINISTÉRIO DA EDUCAÇÃO - MEC. Disponível em http://portal.mec.gov.br/index.php?Itemid=86\&id=116\&option=com_content\&view=article Acesso em 19 nov. 2012a.

MINISTÉRIO DA EDUCAÇÃO - MEC. Portal do MEC. Disponível em http://portal.mec.gov.br/arquivos/pdf/diretrizes.pdf. Acesso em 19 nov. 2012b.

MINISTÉRIO DA EDUCAÇÃO - MEC. Parecer CNE/CO no 29/2002. Disponível em http://portal.mec.gov.br/setec/arquivos/pdf_legislacao/rede/legisla_rede_parecer292002.pd f. Acesso em 24 nov. 2012c.

NEVES, Abilio A. B. CAPES: 50 anos a serviço da pós-graduação. In: FERREIRA, Marieta de M. e MOREIRA, Regina da L (org.). Capes, 50 anos. Disponível em http://cpdoc.fgv.br/producao_intelectual/arq/1319.pdf. Acesso em 30 nov. 2012.

NICOLINI, Alexandre Mendes. A graduação em administração no Brasil: uma análise das políticas públicas. Dissertação. Fundação Getúlio Vargas/Escola Brasileira de Administração Pública, 2000. 
NICOLINI, Alexandre. Qual será o futuro das fábricas de administradores? RAE, v. 43, n. 2, abr./mai./jun., 2003a.

NICOLINI, Alexandre Mendes. Fatores condicionantes do desenvolvimento do ensino de administração no Brasil. Revista ANGRAD, v. 4, p. 3-17, 2003b.

NICOLINI, Alexandre. A trajetória do ensino de administração analisada por um binóculo institucional: lições para um novo caminho. XXVIII Encontro da ANPAD. Curitiba/PR, 2004.

PELEIAS, Ivam Ricardo et. al. Evolução do ensino da contabilidade no brasil: uma análise histórica. Revista Contabilidade e Finanças - USP, São Paulo, v. 18, n. spe, p. 19-32, jun., 2007.

RIBEIRO, Antonio de Lima. A origem e a evolução do ensino da administração no Brasil. Disponível em http://www.cra-rj.org.br/site/espaco_opiniao/arquivos/art063.pdf. Acesso em 20 nov. 2012.

RIBEIRO, Darcy. Sobre o óbvio. Biolinguagem.com, 1986. Disponível em http://www.biolinguagem.com/biolinguagem_antropologia/ribeiro_1986_sobreoobvio.pdf. Acesso em 18 nov. 2012.

ROMUALDO, Cláudio. 0 ensino superior e o cenário do curso de administração no Brasil: uma análise crítica. Empreendedorismo, Gestão e Negócios, v. 1, n. 1, p. 105-123, fev., 2012.

SILVA, Manuela R. da e FISCHER, Tânia. Ensino de Administração: um estudo da trajetória curricular de cursos de graduação. XXXII Encontro da ANPAD. Rio de Janeiro/RJ, 2008.

SOUZA, Hugo Luiz de. Proposta para o ensino da qualidade na graduação em administração com base na experiência da engenharia de produção. Dissertação. Universidade Metodista de Piracicaba, 2006.

STALLIVIERI, Luciane. 0 sistema de ensino superior do Brasil: características, tendências e perspectivas. Disponível em

http://www.ucs.br/ucs/tplCooperacaoCapa/cooperacao/assessoria/artigos/sistema_ensino_ superior.pdf. Acesso em 20 nov. 2012.

TEIXEIRA, Anísio. Ensino superior no Brasil. Rio de Janeiro: Fundação Getúlio Vargas, 1989.

VERGARA, Sylvia Constant. Projetos e relatórios de pesquisa em administração. 5. ed. São Paulo: Atlas, 2004. 